\title{
13 Russian ballet in the age of Petipa
}

\author{
LY N N G R A F O L A
}

On 24 May 1847 Marius Petipa, a young French-born dancer and ballet master, landed in St Petersburg. ${ }^{1}$ He was not the first dance artist to brave the long journey to Russia and the rigours of a Russian winter, nor even the only Petipa; only five months later, his own father signed a contract to teach the senior classes at the Imperial Ballet School. ${ }^{2}$ Like so many other danseurs, Petipa fils was drawn to the "Venice of the North" because of decreasing opportunities for male dancers in the West and the unusually generous terms of an imperial contract, in his case, 10,000 francs a year and "half a benefit" for the position of premier danseur. ${ }^{3}$ He accepted the offer with alacrity, little imagining that he would remain in Russia until his death in 1910, marry twice there (both times to Russian ballerinas), raise a family and rule the Imperial Ballet from 1869, when he became chief ballet master, to his retirement in 1903.

Petipa's long stewardship of the company had an incalculable effect on Russian ballet. He presided over the shift from romanticism to what is usually termed ballet "classicism", laid the foundation of the modern Russian school by marrying the new Italian bravura technique to its more lyrical French counterpart and helped transform an art dominated by foreigners and identified with the West into a Russian national expression. Petipa choreographed scores of ballets and innumerable dances, codifying their structure while expanding the lexicon of their movements, and created several generations of distinguished dancers. His works that survive, even in much altered form, La Bayadère (1877), Giselle (which he revived and significantly revised in 1884), Swan Lake (which he choreographed in 1895 with his assistant Lev Ivanov), Raymonda (1898), above all The Sleeping Beauty (1890), are the classics of an art with a performance tradition that goes back no further than the romantic period. Even if the designation of these works as "classics" came in the twentieth century and reflected a desire to establish a canon in the face of modernism, the fact remains that both in Russia and the West this canon was overwhelmingly identified with Petipa. Indeed, what we call "Russian ballet" in terms of repertory and style is virtually synonymous with Petipa, his colleagues and descendants.

The Imperial Ballet, renamed the Kirov Ballet during the Soviet period and the Maryinsky Ballet after the fall of the Soviet Union, is one of the [151] world's oldest companies. It celebrated its 200th anniversary in 1983, but 
its origins date back to the 1730s and the court entertainments organised by Empress Anna Ivanovna. Although Russia was rich in folk performance traditions, ballet was an imported art nestled in the lap of the court. Ballet masters came from abroad (usually from France and Italy) and brought to Russia the dance fashions of the West. The first dance master of note was Jean-Baptiste Landé, who petitioned the empress for permission to establish a school to train dancers for court performances; the training was to take three years. In 1738 the first ballet school in Russia opened its doors, first in Landé's house, then in one of the wings of the imperial palace. The twenty-four pupils were children of palace servants. ${ }^{4}$ The imperial court was generous to foreigners, especially artists, paying and treating them far better than the Russians who worked for them and whom they sometimes despised. In the decades following the establishment of Landé's school, numerous ballet masters made their way to St Petersburg. Sometimes they brought dancers with them, but by the 1760s, when the ballet d'action arrived in Russia with Franz Hilverding and Gaspero Angiolini, Petersburg-trained dancers could hold their own with foreign performers.

By then, the Imperial Theatres had come into existence. This state system, founded by decree of Catherine the Great in 1756, gave official status to the imperial opera, ballet and drama troupes, as well as the theatre school, and instituted pensions for artists. ${ }^{5}$ The system was fully subsidised, with funding from the Ministry of the Court; it survived even the upheavals of the 1917 Russian Revolution. Suitably renamed, the former Imperial Theatres were nationalised and supported in full by the new Soviet state. When the socialist state collapsed in the 1990s, the post-Soviet government continued to pay for them. The state system had become so deeply entrenched that it outlasted any single form of government.

In 1783 the St Petersburg ballet moved into its first real home, the Bolshoi (not to be confused with the Moscow theatre of the same name) or Kamenny ("stone") Theatre, a huge, neoclassical building seating 2,000, opposite the site where the Maryinsky Theatre now stands. In 1885 the Imperial Ballet moved across the street to the Maryinsky, which remains the company's home today. Thus it was at the Bolshoi Theatre that most of the company's nineteenth-century history played out. Here, romantic sylphs took flight and designers from abroad created marvels of baroque perspective or shipwrecks on the high seas, as in Andreas Roller's famous design for Le Corsaire (1858). ${ }^{6}$ There were scene-painting shops, costume shops and the finest stage machinery that money could buy. Dance personalities of the first rank found their way to St Petersburg, spending, in some cases, years with the company. Filippo Taglioni revived most of his ballets for the company, including La Sylphide, ${ }^{7}$ which starred his daughter, Marie Taglioni, the most celebrated of romantic ballerinas. Balletomanes, a term coined in Russia for 
fanatical enthusiasts of ballet, crowded her performances and even, it is said, sipped champagne from her ballet slipper. "Taglioni is the synonym of Air!" enthused the novelist Nikolay Gogol. "Nothing more ethereal had existed heretofore on the stage."8 Théophile Gautier, perhaps the foremost French dance critic of the time, visited St Petersburg in the 1850s. In Voyage en Russie (1858) he had nothing but praise for the Petersburg company: "The Russians are great connoisseurs ... and the dancer who has withstood the marksmanship of their opera-glasses must be very confident of herself." This was the Russia to which Petipa had come.

Marius Ivanovich Petipa, to give him his full Russian name, was born in Marseilles in 1818. Like so many nineteenth-century dancers, he came from a theatrical family. His father, Jean-Antoine Petipa, was a dancer and ballet master, his mother an actress who gave up the stage to raise a family. ${ }^{10}$ His brother Lucien danced the role of Albrecht in the first Giselle (1841) and later became a ballet master at the Paris Opéra. Jean-Antoine was his son's first dance teacher. "At seven", Marius wrote in his memoirs many years later, "I started instruction in the art of dancing in the class of my father, who broke many bows on my hands in order to acquaint me with the mysteries of choreography." ${ }^{11}$ He made his stage debut in Brussels at the age of nine in a ballet staged by his father and as a student danced in several of Jean-Antoine's original works. He got his first job in Nantes where he choreographed his first ballets, toured the United States with a small company organised by his father, ${ }^{12}$ then settled in Paris to study with Auguste Vestris, one of the great teachers of the French school and a strict custodian of the academic tradition. Nevertheless, a place in the Paris sun eluded him. In 1847 he set out for St Petersburg and, except for vacations and the occasional sabbatical, never left.

During his first fifteen years in Russia, Petipa honed the craft that would distinguish his mature productions. Jules Perrot, the greatest of the romantic-era choreographers who spent more than a decade in St Petersburg, exerted a major influence over Petipa. Petipa danced in several of Perrot's ballets and also served as his assistant, at times even as his collaborator, rehearsing the "great pas stratégique" from Catarina and staging Giselle (1850) for Carlotta Grisi's Russian debut under the watchful eye of his mentor. A second influence on Petipa during these formative years as a choreographer was Arthur Saint-Léon, who followed Perrot to Russia in 1859 and held the post of ballet master for eleven successive seasons. A violinist of the Paganini school and sometime composer, Saint-Léon was an enormously musical choreographer; he had a facility for arranging dances, a fertile imagination and a gift for showing his dancers at their best.

In 1862 Petipa produced his first great success, The Daughter of Pharaoh. He had been working on it for nearly two years, commissioning a libretto 


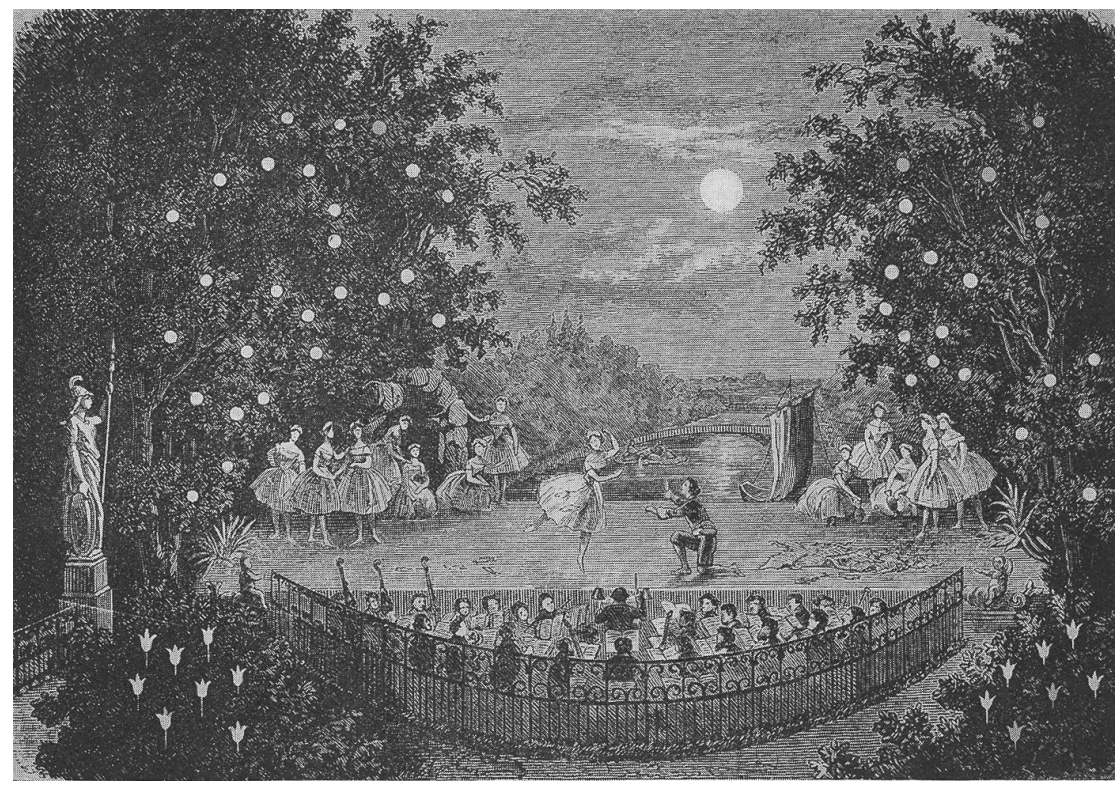

Figure 26 Gala performance at Peterhof, 11 July 1851, from Geirot's Opisanie Petergofa, 1868 (Carlotta Grisi and Jules Perrot in The Naiade and the Fisherman).

from Vernoy de Saint-Georges, who had written the "book" for Giselle and other ballets and a score from Cesare Pugni, a prolific ballet composer in the employ of the Imperial Theatres. A "grand ballet" in three acts and nine scenes, with prologue and epilogue, The Daughter of Pharaoh was set in Egypt. Gautier's short story “The Romance of the Mummy" (1857) inspired the plot, but the excitement generated by Egypt's fabulous monuments and the building of the Suez Canal gave the subject a topical interest.

The ballet was monumental in scale and a melodramatic tour de force. It was also a huge success, and Petipa was promoted to the rank of second ballet master. In 1869 came another success, Don Quixote, a ballet that has enjoyed continuous theatrical life. That year, promoted to chief ballet master, Petipa became sole master of Russia's choreographic revels. In his hands rested the fate of more than a half-dozen imperial enterprises: two theatres (the Bolshoi and the Maryinsky), a company, a school and several smaller court theatres (the Hermitage, Peterhof, Tsarskoe Selo, Krasnoe Selo and Kamennyi Ostrov) (see Fig. 26). ${ }^{13}$

Like the romantic ballets that fed his imagination, Petipa's works told stories. Many were romances touched with old-fashioned melodrama, with heroines who died of broken hearts or suffered in some way before wedding their rightful mates. Like their romantic predecessors, Petipa's ballets were always about women; more often than not, they took their titles from the heroine - hence, The Daughter of Pharaoh (1862), La Bayadère (1877), The Sleeping Beauty (1890), Raymonda (1898) and many others. Petipa revelled 
in his ballerinas, and in work after work, generation after generation, he displayed their growing prowess as technicians and their personalities as artists.

Although the romantic ballet had already identified the ballerina with the feminine mystique, emphasising her elusiveness and ethereality, Petipa added technical brilliance to the formula. In the post-romantic era, ballet technique developed rapidly, above all in Italy. By the 1860s the blocked shoe had come into use with its greater support; dancers began to run, jump, hop and perform multiple turns on pointe. Skirts rose, revealing greater expanses of leg and the prowess of "steel" toes. Not everyone welcomed the new virtuosity. To many the modern ballerina seemed akin to a machine, a miracle of industrial precision, nowhere more so than in the multiple fouetté turns introduced into Russia by visiting Italian ballerinas in the late $1880 \mathrm{~s}$ and 1890s.

The emphasis on drill, as essential to the handling of Petipa's stage masses as to the manipulation of armies of "ballet girls" in the spectacular ballets popular in Western Europe and the United States, was another aspect of this mechanisation. Standing backstage at the Théâtre de la Gaîté in 1873, an American observer compared the production of an opéra féerie, with its spectacle effects and army of dancers, to "the manoeuvring of the great machine, which night after night worked so smoothly and so beautifully before the public". ${ }^{14}$ Finally, unlike the sylphs and other romantic emblems of eternal girlhood, the ballerina of the closing decades of the nineteenth century was a full-bodied woman, wasp-waisted, corseted and glamorous, fully cognisant, when she stepped out on stage, of her star power. Utterly different from the chaste, "Christian" image of ballerinas like Marie Taglioni, she dominated the stage by her presence, not by the premonition of her absence. With flesh, sexuality and power as her weapons, she was all too real, anything but a metaphor for the spirit.

Petipa jettisoned other romantic conventions as well. Most romantic ballets (or "ballet-pantomimes", as they were usually called) consisted of two acts and were typically performed on a bill with opera. Petipa's ballets, by contrast, were usually three or four acts, full-evening entertainments. His ballets may have told stories like their romantic predecessors, but they embedded those stories in a vast array of dances and transformation scenes that enhanced the spectacular aspect of his work, while undermining its narrative power. Bigger meant better, so revising meant adding rather than trimming material. Instead of offering a simple contrast with the preceding realistic act, as in La Sylphide or Giselle, Petipa's ballet blanc was a jewel in an ever more elaborate setting.

In 1874 August Bournonville visited St Petersburg and saw several of Petipa's ballets, including The Daughter of Pharaoh and Don Quixote. Although he admired the "richly imaginative arrangement of the settings 
and transformations", the corps of more than two hundred and the "superb talent that displayed itself especially among the female members", the Danish ballet master was also shocked by what he saw:

I sought in vain to discover plot, dramatic interest, logical consistency, or anything which might remotely resemble sanity. And even if I were fortunate enough to come upon a trace of it in Petipa's Don Quixote, the impression was immediately effaced by an unending and monotonous host of feats of bravura, all of which were rewarded with salvos of applause and curtain calls. $^{15}$

Bournonville also found appalling the "lascivious tendency" that pervaded "the whole ballet movement", except for the Slavic national dances. He hated the women's "excessively short skirts" and the "regulation caleçons de bain", swimming trunks, that were "an established fact for the danseurs". 16

However, at this very moment, Petipa was creating what a later generation would regard as a defining moment in the genesis of Russian classicism the "Kingdom of the Shades" in La Bayadère. Produced in 1877 to a score by Ludwig Minkus, the ballet marked Petipa's maturity as a choreographer, with the "Shades scene" regarded as both a masterpiece of classical style and one of his greatest dances. Here, in a story bathed in the romantic exoticism of The Daughter of Pharaoh, was Petipa's vision of classical heaven - fortyeight moonlit women in white descending one by one from the Himalayas and winding slowly forward, all the while performing a simple arabesque phrase with the hypnotic deliberateness of ritual.

Although the Imperial Ballet was largely insulated from outside events, the 1880s were a time of change. In 1881 Prince Ivan Vsevolozhsky became the new director of the Imperial Theatres. In contrast to his predecessors, Vsevolozhsky was cultured, well-educated and polished, a European in speech and manners. ${ }^{17}$ Petipa adored him and the seventeen years that followed his appointment were Petipa's happiest and most productive. As conceived by Vsevolozhsky, the Maryinsky Theatre, where the Imperial Ballet began to perform in 1885, was to be the temple of an art outside time, unsullied by ugly nationalism, untouched by change except in "safe" or ideologically neutral matters such as staging, technique and personnel. Vsevolozhsky was above all a courtier and under his rule the Imperial Ballet may have reached its apogee. But it did so at the price of cultural isolation; at no time did the company find itself so divorced from the society around it or from the artistic trends - nationalism, realism, symbolism that transformed the Russian cultural landscape between the 1870s and early 1900s. Rather than a fully national art, ballet in nineteenth-century Russia remained an appendage of the court. 
In 1882 the monopoly of the Imperial Theatres was abolished, and for the first time ballet audiences in cities like St Petersburg and Moscow could see companies and entertainments from abroad. People flocked to the new establishments, although critics disagreed over the merits of the offerings, which included operettas, variety programmes and ballets-féeries. In marked contrast to the "grand ballet" as it had developed in Russia, the ballet-féerie depended on effects so spectacular as to overwhelm both the choreography and the story; at the same time it introduced the public to a new generation of virtuoso Italian ballerinas. However much Vsevolozhsky might disdain the new trends, he could hardly deny their appeal, and in several works of the mid- and late 1880s, he borrowed judiciously and selectively from the new genre.

Gradually, his vision of the Imperial Ballet took shape, which, as Roland John Wiley suggests, united "the dance-intensive grand ballet long favoured in Petersburg and the extraordinary mise-en-scène of the Franco-Italian féerie ... Vsevolozhsky wanted to match the West European fashion for grandiose staging, then better it with elegant choreography and sophisticated music, which the West European model lacked." 18 He abolished the post of official ballet composer, thus partly abandoning the "specialist" tradition of nineteenth-century ballet music and sought "to develop new sources of ballet scores, principally from Russian composers". ${ }^{19}$

It was Vsevolozhsky who initiated the collaboration between Petipa and Tchaikovsky that became The Sleeping Beauty. "I have thought of writing a libretto based on Perrault's story 'La Belle au Bois Dormant'” he wrote to the composer in 1888. "I want to do the mise-en-scène in the style of Louis XIV. Here one can let one's musical fantasy play - and create melodies in the spirit of Lully, Bach, Rameau and so on. If the idea is to your liking, why couldn't you undertake the composition of the music?"20 Tchaikovsky allowed himself to be tempted. "The subject is so poetic", he wrote to his patron Nadezhda von Meck, "so gratifying for music, that I was captivated by it." 21 Two years later the ballet was a reality. Petipa was fully aware of the importance of the collaboration. For the first time he was working with a major composer from outside the ballet "specialist" tradition, probably Russia's most distinguished musical artist. But Petipa did not significantly alter his usual working method. He wrote out a detailed plan for the ballet, breaking it down by section and for each section, describing the action, the quality of the music he wanted, the time signature, length (in terms of bars) and even suggestions for orchestration. ${ }^{22}$ Tchaikovsky, for his part, responded with inventiveness to Petipa's call for expressive effects and almost always complied with his instructions regarding metre, tempo or scoring. The result was a score that followed the conventions of nineteenth-century ballet, even as it invested them with unusually high artistic quality. 
The Sleeping Beauty premiered in 1890 and despite initial criticism of its weak libretto, féerie-style lavishness and Gallic source and setting, was soon hailed as a masterpiece. ${ }^{23}$ The chief reason, wrote Alexandre Benois, was the music, which inspired Petipa to "a height of perfection hitherto unsurpassed by him. It is enough to recall the variations of the fairies in the prologue, the grand pas de deux in the third scene and, the greatest masterpiece of all, the dance of the Blue Bird and the enchanted Princess. But what innumerable other gems of choreographic art are scattered by Petipa throughout."24

A grand spectacle, four hours long, with a prologue, three acts and an apotheosis, Beauty was a summation of the conventions elaborated over the course of the century. Like all of Petipa's ballets, it drew on a multiplicity of movement idioms. There were long mime scenes, dances in national dance style, ballroom dances, as well as classical dancing in the vision scene, divertissements and a grand pas d'action.

It is impossible today even to imagine the human density on the imperial stage of the late nineteenth century. In 1903-4 the Imperial Ballet consisted of 122 female and 92 male dancers, plus ballet masters and régisseurs. ${ }^{25}$ In addition, there were the children and advanced students of the ballet school, regularly used in productions. Dozens of them appeared in The Sleeping Beauty, as Cupids, pages, "young girls" with lutes, Tom Thumb and his brothers; in the Garland Waltz alone there were twenty-four children. Finally, there were the drama students and members of the imperial drama troupe, sometimes pressed into action as supers; in a pinch soldiers from one of the elite guards units stationed in St Petersburg could be called upon. The imperial stage teemed with life.

It also mirrored the hierarchy that governed all aspects of imperial life. Ranks determined the minimum or maximum number of dancers who could appear in a group. Coryphées could dance in groups of no more than eight; second soloists in groups of no more than four; first dancers in groups of no more than two. The ballerina danced alone. Thus hierarchy was built into the very substance of the choreography. It also went to the heart of the ballet's social "message". Sleeping Beauty, like Swan Lake (1895) and Raymonda (1898), invokes a monarchical ideal of the well-ordered polity ruled by its rightful king. Hence, the obsession in all three ballets with marriage as source of continuity in an absolutist state and the risk of choosing an inappropriate mate or (in the case of Aurora) no mate at all. The chaos produced by Carabosse in Sleeping Beauty, Odile in Swan Lake and Abderrakhman in Raymonda suggests that what is really at stake in these ballets is the idea of autocracy itself. To be sure none of these ballets (or any other ballets produced during Vsevolozhsky's directorship) takes place in Russia. But in their court settings and in the storyline that identifies them 
with outmoded forms of government, they celebrated a political vision that pointed directly to the Romanovs.

Sleeping Beauty and its successors, especially Swan Lake and Raymonda, offered a veritable encyclopedia of the codified forms constituting Petipa's "classicism". Among these was the grand pas de deux, a virtuoso dance for the ballerina and her partner that marked the climactic end of an act. Petipa did not invent the pas de deux, but he significantly transformed it, codifying it as a multi-part number that opened with a supported adagio, continued with one or two pairs of variations and ended in a triumphant coda. Just as Petipa had codified the pas de deux, so he did the same with the virtuoso variation. It was in three parts, with repeats, so that what was done first on one side was repeated on the other. Unlike the transitional ballets of the late 1880s, Sleeping Beauty did not simply display the new technical developments associated with the Italian school. Rather, for the first time, Petipa succeeded in fusing them with the elegance of the French school, the basis of traditional Russian training. This synthesis laid the foundation of the modern Russian school.

Petipa also brought a very high degree of perfection to what is sometimes called the grand pas or grand pas d'action. This was the climax of a ballet, a dance in classical style for a ballerina, premier danseur, soloists and corps de ballet that generalised the main idea of the ballet. ${ }^{26}$ Although the number of characters might vary, a grand pas typically included the ballet's protagonists along with soloists, coryphées and corps members. The grand pas had a high degree of formal unity but little narrative function, the reason it could easily be extracted from the surrounding ballet and performed independently. The "Jardin Animé" in Le Corsaire is one such dance; another the grand pas of Paquita; still another the grand pas classique (also called the grand pas Hongrois) in Act III of Raymonda.

In the flush of excitement that followed the success of The Sleeping Beauty, Tchaikovsky agreed to do another ballet, The Nutcracker. Amazingly, given its longevity and protean identity, the ballet was ill-starred. Tchaikovsky disliked the libretto, based on a story by E. T. A. Hoffmann, and after the ballet went into rehearsal, Petipa fell ill and turned the choreography over to his assistant ballet master, Lev Ivanov. When the ballet finally opened in 1892, it met with sharp criticism. "Nutcracker can in no event be called a ballet," wrote one critic. ${ }^{27}$

Three years later, Swan Lake, the most iconic of nineteenth-century ballets, came to life at the Maryinsky. Petipa had choreographed Act I and most of Act III, the ball scene, including the "Black Swan" pas de deux for Odette's look-alike, Odile: the two roles were danced by the same ballerina. Here, writes Krasovskaya, Petipa “brilliantly [set] off Ivanov's Odette, with her elegiac arabesques, against Odile, the bird of prey, with her resilient and 


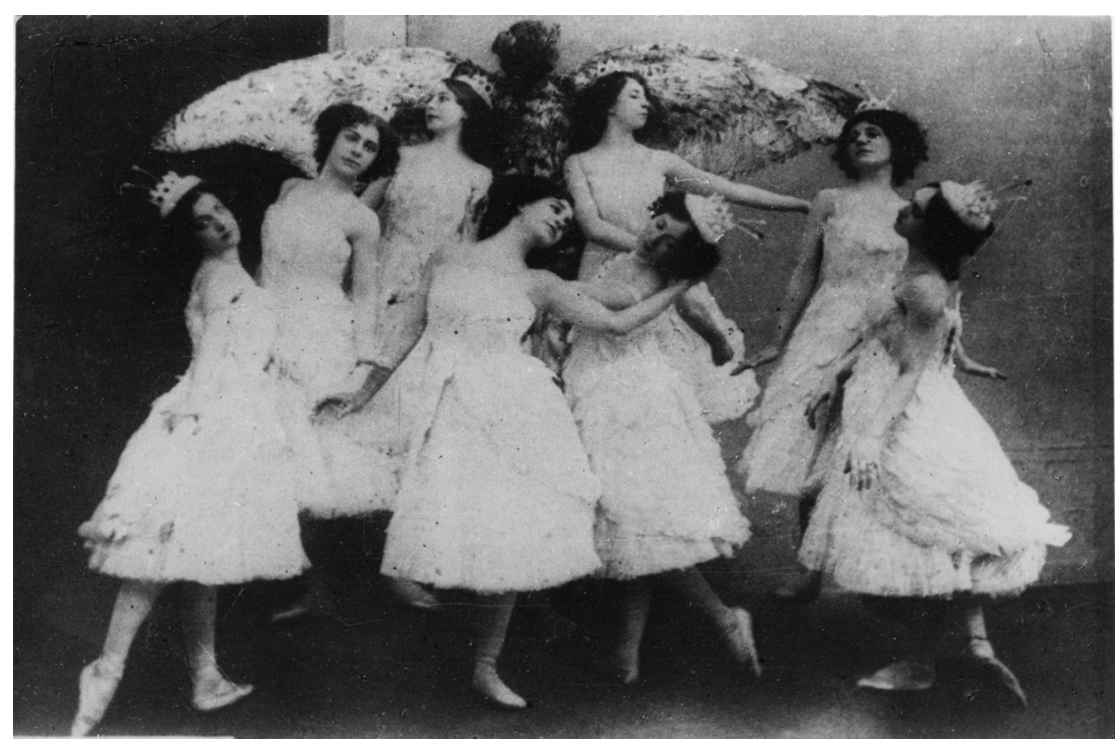

Figure 27 Swan Lake, St Petersburg 1910, choreography by Lev Ivanov and Marius Petipa, music by Pyotr Ilyich Tchaikovsky.

commanding attitudes. His skill triumphed in the fouette" - a sequence of thirty-two of those highly virtuosic turns - "which was no longer a technical stunt but the culmination in the depiction of cunning temptation: the swift repetition of the dancer's spins put the finishing touches to Odile's character." ${ }^{28}$ Although Ivanov choreographed the lakeside dances of the last act, Petipa sketched out at least some of the action. He identified the dancers of various numbers and pondered the colour scheme of the costumes, deciding on black and white to underscore the theme of moral guilt and the presentiment of death. ${ }^{29}$ The intonation of sorrow was intensified in the waltz, when the black swans cut through the lines of white swans and climaxed at the end of the act, when first Odette, then Siegfried died by their own hands, thereby breaking the spell. With the lovers united in death, Rothbart, the "evil genie", as he was called in the libretto, fell dead. In the apotheosis the lovers appeared in the clouds, seated on enormous swans, ${ }^{30}$ giving the ballet a happy, if banal, ending (see Figs. 27 and 28).

Apart from Giselle, which Petipa revived and significantly revised in 1884, what survives of his work comes from the 1890s or turn-of-the-century recensions of earlier works such as La Bayadère, Le Corsaire and Don Quixote (although how much of Petipa remains in Aleksandr Gorsky's 1902 restaging is a matter of debate). Part of the reason these works have survived is because they were choreographed or revised towards the end of Petipa's career, thus representing his last word, so to speak, on an art that he had spent the previous fifty years perfecting. They also survive because they comprised 
the stock of works belonging to the "old ballet", as Petipa's work began to be called around 1910, that dancers of the 1910s and 1920s brought with them to the West and that the post-revolutionary generation in Russia made the cornerstone of the Soviet, "academic" repertory. Finally, the ballets of the 1890s have survived because of their high musical quality. This was especially true in the West, where Diaghilev's revolution in ballet music made composers like Pugni and Minkus sound hopelessly old-fashioned. It was not until the early 1960s, when the Kirov began to tour outside the Soviet bloc, that the "Kingdom of the Shades" was introduced to Western audiences. Le Corsaire and Don Quixote came later.

Although Russian ballet of the 1890s revealed an even greater Western focus than in previous decades, the number of foreigners in the Petersburg company was actually declining. Visiting ballerinas came and went, but with the departure of Pierina Legnani, the first Petersburg OdetteOdile, they pretty much left for good. Now, led by Mathilde Kshesinska, the company's prima ballerina assoluta, an extraordinary generation of Russian talent emerged from the Imperial Ballet School. The dancers themselves differed from their nineteenth-century predecessors in several important ways. Not only had the social class of the dancers risen, but so had salaries. Although these were not especially generous, they were far more than the pittance of the 1870s, when members of the corps earned between 174 and 240 roubles a year. (Yekaterina Vazem, the highest paid member of the company, received 1,143 roubles in salary plus 25 roubles per performance.) $)^{31}$ Conditions at the school had also improved and memoirists like Tamara Karsavina describe the ample meals and generous allotment of clothing that the children received, regardless of means. A growing number of dancers, including Mikhail Fokine and Adolph Bolm, came from merchant families, a sure sign that the social status of the dancer was on the rise. Many dancers were now the children, siblings, or spouses of dancers, members of clans that formed an increasingly privileged caste within the Russian theatrical world. Some, like the Kshesinskys, were quite well off. Others, like the Karsavins, lived in "reduced circumstances" on the father's small pension and meagre salary as a part-time teacher. ${ }^{32}$ Nevertheless, conditions at the end of the nineteenth century were far better than at mid-century, when poverty was well-nigh universal. ${ }^{33}$

Finally, the training had significantly changed during Petipa's years in Russia. Students who attended the Imperial Theatre School in the 1830s and 1840s studied acting, singing as well as dancing and were then placed according to their talents. By the 1890s ballet training had become highly specialised (although students continued to study music as well as academic subjects). ${ }^{34}$ The result was a company with a very high degree of professionalism, which compared favourably with standards elsewhere in 


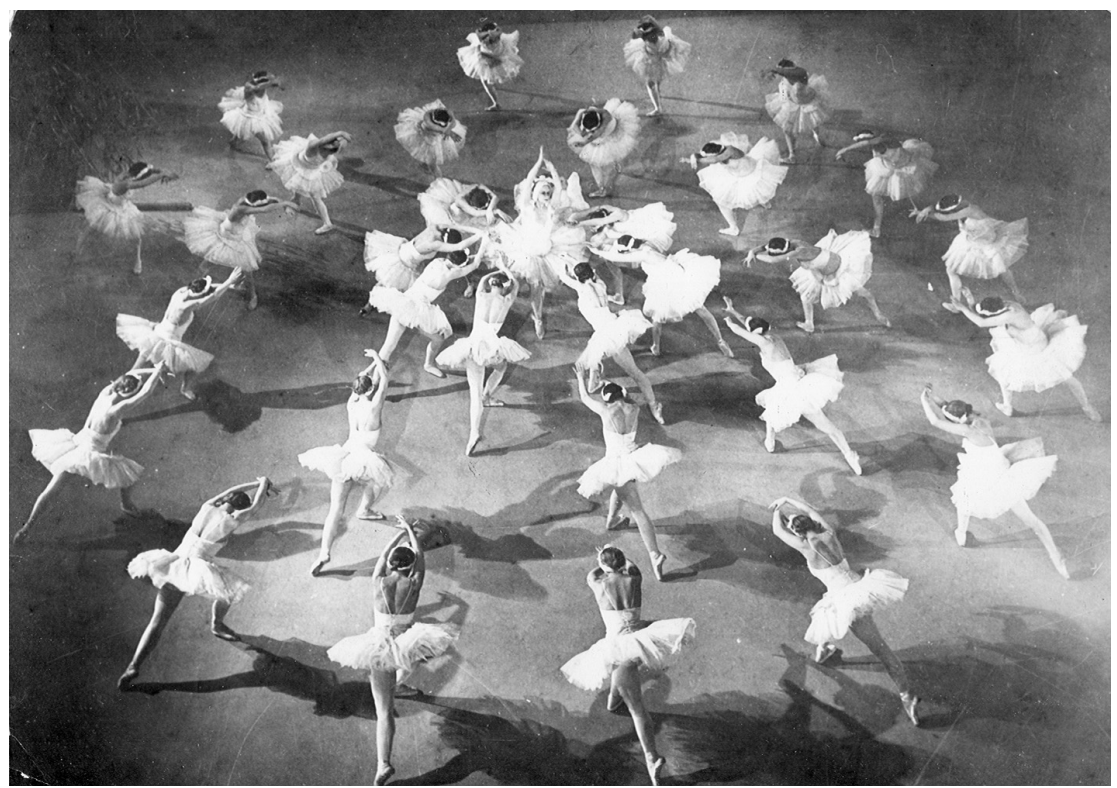

Figure 28 Scene from Swan Lake, Bolshoi Ballet Moscow, 1959.

Europe, as became evident once the ban on private theatrical enterprise was lifted.

Despite the social changes, liaisons remained a fact of life. Some "protectors" eventually married the women who had been their lovers: this was the case of Agrippina Vaganova, the legendary Soviet-era pedagogue and her husband, Andrey Pomerantsev, ${ }^{35}$ as well as Anna Pavlova and Victor Dandré. Kshesinska reserved her favours for Romanovs - first, the future Nicholas II, then his cousins, Grand Duke Sergey and Grand Duke André, whom she married years later in emigration. She collected houses as well as jewels and was not averse to throwing around her power. When Vsevolozhsky's successor (and nephew), Prince Serge Volkonsky, fined her for an unauthorised change of costume in the ballet Camargo (1872), she went straight to her former lover, Nicholas II, who requested that the fine be annulled. In Volkonsky's audience with Nicholas, he tried to explain "the impossible conditions ... produced by interference with my dispositions, owing to the exceptional position in which one dancer was placed and her precedence before all the others" ${ }^{36}$ Volkonsky ended by requesting permission to resign.

This incident, which took place in 1901, underscored the very close relationship between the Romanovs and the ballet. Members of the imperial family celebrated birthdays and name-days at the ballet; they attended school performances and distributed chocolates to the children; they made friends with the dancers, weighed in on performances, used their influence to promote their favourites and sometimes found mistresses. "How happy 
we felt at the thought of being allowed to dance in the presence of the Imperial Family!" exclaimed Kshesinska, recalling the school performance when Alexander III singled her out for praise. ${ }^{37}$ Far more than any of the other arts, ballet in Russia was a reflection of what Richard Taruskin has called, "the last surviving eighteenth-century (hierarchical, aristocratic) society in Europe".38

Although Petipa remained very much a Frenchman, it was under his require that the Imperial Ballet began the slow transformation from an art of the court, understood in the broadest sense, to an art of the nation. By the 1890s nationalism was a recurring theme in ballet criticism, both with regard to genres like the féerie and foreign ballerinas who did not find favour with Russian audiences. Ironically, this identity was only fully realised after the triumph of Diaghilev's Ballets Russes in Paris beginning in 1909. Even though the Ballets Russes never performed in Russia and exemplified the "new ballet", it created for Russian ballet, old and new, a place in the European cultural imaginary and the international cultural marketplace.

By then the age of Petipa was long over and Russian ballet had ceased to be a purely Russian phenomenon. Now, through the diaspora of Russian dancers in the 1910s and 1920s, his last generation of dancers extended his influence far beyond the Imperial Theatres where Petipa had spent his most productive years. In an art where oblivion is the fate of all but the tiniest minority of works, his ballets, virtually unknown outside Russia during his lifetime, have become the "classics" of a common heritage, while his school, updated and transformed, continues to be its lingua franca. 